\title{
Wisdom and Emotion: Galen's Philosophical Position in Avoiding Distress
}

\author{
Teun Tieleman
}

\section{Introduction}

Soon after its recovery in 2005, Galen's Avoiding Distress ( $\pi \varepsilon p i$ $\alpha \lambda \nu \pi i \alpha \varsigma$ ) was recognized as an extremely important new source of information on its author's life and times. Writing shortly after the murder of the emperor Commodus (192 CE) Galen provides intriguing glimpses of the latter's reign of terror, at least as experienced by members of the imperial court and the senatorial circles in which he moved (esp. $§ \S 54-57 ;$ cf. 50). In addition, scholars were intrigued by what Galen tells us about his collection of books and the libraries of Rome which had been destroyed by the great fire that struck Rome at the end of 192 CE. This 'cultural catastrophe' (in Vegetti's apt phrase) ${ }^{1}$ is presented as the immediate occasion for the writing of the tract: a long-standing friend of Galen's from his native Pergamum (who however remains anonymous) has sent him a letter asking how Galen managed to cope with this terrible blow, which not only involved books by himself and other authors but also drugs, recipes for drugs as well as medical instruments. In particular, the friend is curious to know how Galen had avoided succumbing to distress $(\lambda \dot{\tau} \pi \eta)$. On Avoiding Distress (hereafter Ind.), a 'letter-treatise,'2 is Galen's reply and clearly a very personal kind of document. At the same time, it clearly stands in a literary and philosophical tradition. Christopher Gill ${ }^{3}$ has pointed out that it invites comparison with Plutarch's On

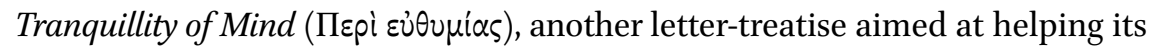

1 Vegetti, M., Galeno. Nuovi scritti autobiografici. Introduzione, traduzione e commento di -. Carocci editore, 2013, p. 254.

2 On this ancient genre see Stirewalt, L.M., Studies in Ancient Greek Epistolography, SBL Resources for Biblical Study 27. Atlanta, GA, Scholars Press, 1993, pp. 18-19; cf. eiusd. 'The Form and Function of the Greek Letter-Essay, in K.P. Dornfried, The Romans Debate. Revised and Expanded Edition, Peabody Mass., Hendrickson Publishers, 1991, pp. 147-171 (p. 152). Cf. Kotzia, P., 'Galen $\pi \varepsilon p i ~ ¿ \lambda v \pi i \alpha \varsigma:$ title, genre and two cruces,' in Manetti, D. ed., Studi sul De Indolentia di Galeno, 2012, pp. 69-92 (p. 69).

3 Gill, C., Naturalistic Psychology in Galen and Stoicism, Oxford, 2010, p. 262. We may also compare Cicero, Tusculans book III.

(C) TEUN TIELEMAN, 2019 | DOI:10.1163/9789004383302_010

This is an open access chapter distributed under the terms of the prevailing CC-BY-NC-ND License at the time of publication. 
readers avoid or at least moderate distress $(465 \mathrm{a}, 465 \mathrm{~d})$. But in fact tracts en-

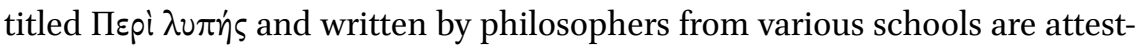
ed from the Hellenistic period onwards, a line comparable to that devoted to other emotions such as the On Anger literature. ${ }^{4}$ Galen's treatise, then, should be considered against the backdrop of ancient philosophical therapeutics with which it shares some of its arguments and exempla, as has been shown by others. In fact, Galen had read and worked on Chrysippus' celebrated Therapeutics (the fourth book of the latter's On Emotions). His refutation of its moral psychology in $P H P$ books IV and $\mathrm{v}$ some thirty years before the writing of Ind. did not keep him from referring to Chrysippus' work as a well-known and useful moral guide in On Affected Parts III, 1 (VIII, p. $138 \mathrm{~K}$. = SVF III, 457). Just as doctors belonging to different medical schools concurred in prescribing particular therapies of proven efficacy, so too the philosophical therapist may be pragmatic about the arguments and exercises he recommends, regardless of their original provenance. This is illustrated by Galen above all.

As has been noted by Nutton, Asmis and others, Galen in Ind. shows himself to be both pragmatic and independent in working out his position on the basis of his philosophical education as well as his own experience, both personal and medical. ${ }^{5}$ But more can and should be done to gauge Galen's acquaintance with philosophical sources and to determine how exactly he uses them to develop his own point of view. Here of course different options were open to Galen. In fact, his position has been associated with the ideal of the moderation of emotion (metriopatheia) and the Aristotelian tradition in particular. ${ }^{6} \mathrm{I}$ want to redress the balance in favour of the Stoic by highlighting what I believe are instances of his discriminating and creative use of Stoic concepts. It is clear that Galen has strong doubts about the possibility of eradicating, in himself and others, all emotions, i.e. the Stoic ideal of complete freedom from emotion, apatheia $(\dot{\alpha} \pi \dot{\alpha} \theta \varepsilon ı \alpha)$. He also distances himself from the moral heroics of the kind exemplified by Stoics such as Musonius (§ 73). Yet Galen’s reminders

4 For some examples see Kotzia, P., 'Galen $\pi \varepsilon p i$ ¿ $\lambda \nu \pi i \alpha \varsigma$ : title, genre and two cruces,' 2012, p. 74.

5 Nutton, V., Galen, Avoiding Distress (translation and introduction) in P. N. Singer et al. (eds.) Galen. Psychological Writings, Cambridge, CuP, 2013, p. 66; Asmis, E. 'Galen's De indolentia and the Creation of a Personal Philosophy,' in Rothschild \& Thompson eds., Galen's De indolentia. Essays on a newly Discovered Letter, 2014, esp. 128-129 ("personal philosophy"); Kaufman, D. H., 'Galen on the Therapy of Distress and the Limits of Emotional Therapy,' Oxford Studies in Ancient Philosophy 47, 2014, pp. 275-296 (p. 294).

6 On the moderation vs. eradication debate in antiquity see Dillon, J., "Metriopatheia and Apatheia": Some Reflections on a Controversy in later Greek ethics,' in J.P. Anton \& A. Preuss (eds.) Essays on Ancient Greek Philosophy, vol. II, 1983, 508-517; Sorabji, R., Emotion and Peace of Mind. From Stoic Agitation to Christian Temptation, Oxford, 2000, pp. 194-210; S. Weisser, Eradication on modération des passions. Histoire de la controverse chez Cicéron et Philon d'Alexandre, Monothéismes et Philosophié, forthcoming from Brepols (Turnhout) (non vidi). 
of our human weakness and vulnerability and the limits of emotion therapy ${ }^{7}$ should not distract us from the fact that he does find a use for several Stoic ideas and arguments. It is not as if the Stoics were content to hold out the distant ideal of the sage: they had developed a complete therapeutics addressing the needs of all those still very much prone to emotion. ${ }^{8}$ But Galen also claims that he feels no emotion whatsoever at least in regard to certain things that most people would experience as extremely painful. This again looks like apatheia rather than all-round metriopatheia. How should we explain this position and how coherent is it?

It useful first to take stock of the attitude to philosophy taken by Galen in these pages. The treatise opens with a reference to the letter of his friend requesting him to disclose which training or which arguments or which doctrines had caused him never to experience distress. ${ }^{9}$ Some translators show a distinct reluctance to render the third option ( $\delta \dot{\gamma} \gamma \mu \alpha \tau \alpha)$ through a term such as 'doctrines' or 'creeds' let alone 'dogmas' as too specific and suggestive of sectarian affiliation..$^{10}$ Although the sentence purports to give the phrasing of Galen's old friend, the latter must have been aware that Galen avoided association with any philosophical school in particular and so did not imply any affiliation on Galen's part. But this seems over-cautious. The dramatic situation implies a long separation between Galen and his friend, who had remained in far-off Pergamum, and now wonders how Galen had succeeded in responding to his great losses with such enviable equanimity. Apart from that, the term in the sense of philosophical doctrine does not commit Galen to the acceptance of all doctrines of any particular school, which would amount to the sectarian attitude he denounces elsewhere. Of course, Galen avoids doctrines unsupported by experience and may use the term in rejecting dogmatism of the speculative

7 On which see further Kaufman, D. H., 'Galen on the Therapy of Distress and the Limits of Emotional Therapy,' Oxford Studies in Ancient Philosophy 47, 2014, pp. 275-296.

8 Stoic therapy starts from the needs and possibilities of the person in the grip of emotion; cf. infra, n. 45 .

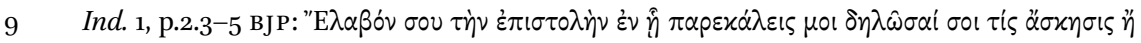

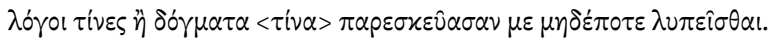

10 Nutton renders 'considerations' (explained in n.3), Boudon and Jouanna's French has 'conceptions,' Lami and Garofalo, however, translate, correctly I think, 'dottrine' and so does Vegetti. Similarly $\lambda$ oroi is rendered 'discours' by Boudon and Jouanna and 'discorsi' by Lami and Garofalo and by Vegetti. Nutton here translate, more precisely, 'arguments.' See also Kotzia, P., 'Galen, De indolentia: Commonplaces, Traditions, and Contexts,' 2014, pp. 96-97. 
kind. But he freely ascribes them to his heroes Hippocrates and Plato, as in the title of his $P H P$, which pertains to doctrines in moral psychology, elementary theory and methodology. ${ }^{11}$ So in Galen's case too, asking about his doctrines comes as a natural question, especially among educated people who look to philosophy for moral guidance..$^{12}$ Elsewhere in Ind. and other works Galen refers to education $(\pi \alpha \iota \delta \varepsilon i \alpha)$ and nature $(\varphi \dot{v} \sigma \varsigma)$ as sources of mental strength and of the ability to avoid distress. ${ }^{13}$ For members of his social class (as his own biography illustrates) this education included philosophy. By opening his tract in this particular way, then, Galen effectively announces that his answer to his friend's question will address his relation to philosophy and philosophical schools, as indeed we find him doing later on. ${ }^{14}$

The linking of doctrines, arguments and training invites comparison with An. Dig. 6.7, p.25.15-19 DB (= v, p. 37 K.), where a young man who is troubled by small matters asks Galen how it is possible that he is not even affected by big ones, "either through training or particular doctrines or natural makeup." ${ }^{15}$ The situation clearly runs parallel to the opening passage of Ind. Here Galen omits mention of natural capacity - only to stress it more forcefully in the later parts of Ind. ( $\S \S 57-59) \cdot{ }^{16}$ This may be a particular emphasis of Galen's. Other authors just give the pair of doctrines and training. ${ }^{17}$ Likewise at An. Dig. 3.14-4.1, p.12-16 De Boer (v, p.4 K.) Galen says that even the person with the best natural aptitude $(\varepsilon \dot{\varphi} \varphi v \varepsilon \sigma \tau \alpha \tau \circ \varsigma)^{18}$ and finest moral education

11 Cf. РНP 3.1.33, 4.7.23. At Loc. Aff. VIII, $191 \mathrm{~K}$ Galen distinguishes common notions (xoเvai

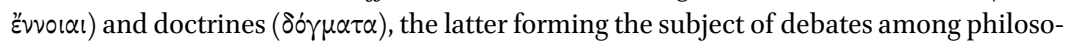
phers and physicians.

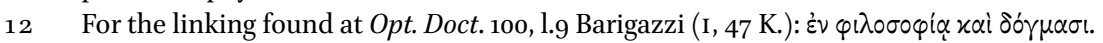

13 They are often linked this way: see Ind. 51, p.16.17-20; ibid. 57, p.18.17-18, 79, p. 24.12-15 BJP. Loc. aff. VIII, p. $301 \mathrm{~K}$.

$14 \S \S 62-68$, on which see infra, pp. 208-211.

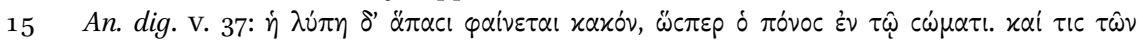

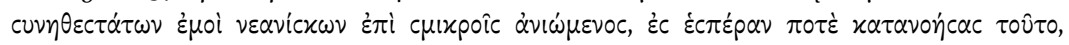

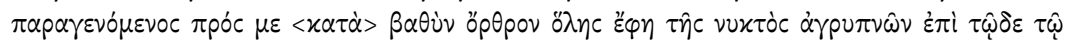

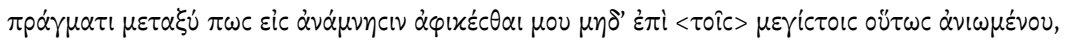

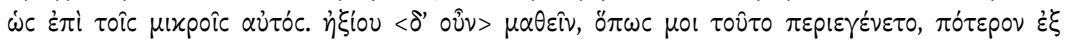

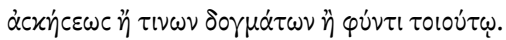

16 Cf. Kaufman, D. H., 'Galen on the Therapy of Distress and the Limits of Emotional Therapy,' 2014, p. 291.

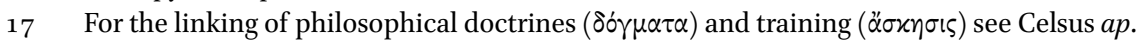
Origenes, Contra Celsum 1.2, l. 4; Hippolytus, Ref. 9.13.6, 9.27.2.

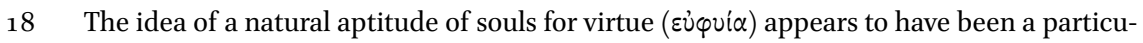
larly Stoic concern. Already Cleanthes devoted a tract to it: $S V F$ I, 481 (p.107, l.15). Another testimony ( $s V F$ III, 366, from Stobaeus) aligns aptitude with being well-born or nobil-

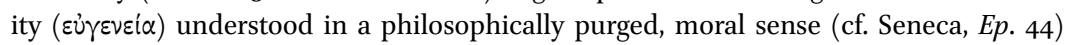
but also refers to a debate among Stoics about the relative contributions towards virtue 
remains fallible so that we remain in need of training ( $\dot{\sigma} \sigma \eta \dot{\sigma} \sigma \varsigma)$ throughout life. Conversely, training is useless for those with no natural aptitude or without an excellent education (Ind. 57, p.18 BJP). The method of training he recommends is imagining that one's worst fears come true, i.e. the technique of

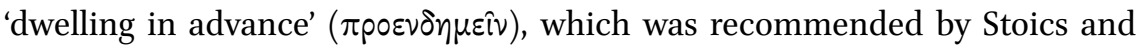
other philosophers. ${ }^{19}$ According to Galen

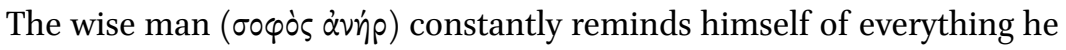

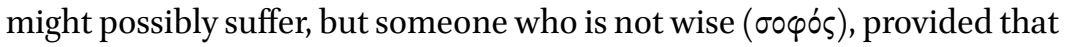
he does not live like an animal, is in some way also stimulated to a knowledge of the human condition by the realities of daily life $(\S 53$, translation Nutton, slightly altered). ${ }^{20}$

Obviously, the wise person as the embodiment of an ideal was never meant to leave the non-wise any excuse for not undertaking the effort of selfimprovement. But Galen's point seems to be that this piece of wisdom is not

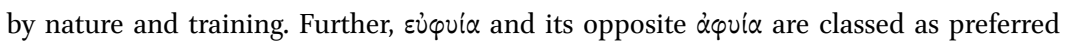
and not-preferred indifferents respectively: $S V F$ III, 127, 135, 136. The Stoic sage will fall in love with young men who show their aptitude for virtue through their countenance: SVF III, 716. Further evidence closer in time to Galen comes from educational contexts in Epictetus: Diss. 1.29.35, 2.16.17, 2.24.28, 3.6.9 (= Musonius fr. 46), 3.6.10 (education reinforces natural aptitude), 3.23.14, 4.10.3; similarly Musonius Rufus: Frs. 46, Diss. 1, l.35, 13b, l.1o. Passages such as the ones just listed show that the Stoics, like e.g. Aristotle before them, recognized that people are born with different capacities for moral virtue; hence this is not peculiar to Galen. Modern scholars however tend to stress the egalitarian nature of Hellenistic therapy, e.g. Kaufman, D. H., 'Galen on the Therapy of Distress and the Limits of Emotional Therapy,' 2014, p. 293: "Epicurean and Stoic therapy [...] are [...] fully applicable to anyone at all, whatever their nature and upbringing."

19 Cic. Tusc. 3.28-31 (with particular reference to distress) ascribes the idea to the Cyrenaics (cf. ibid. 59), but says at $3.5^{2}$ that Chrysippus the Stoic was of the same opinion. Cf. also Seneca, Ad Marciam 9.1-10; 11.1. See Sorabji, R. Emotion and Peace of Mind, 2000, p. 236 for discussion and further references. On the technique in Ind. See Kotzia, P., 'Galen, De indolentia: Commonplaces, Traditions, and Contexts,' 2014, p. 107-114.

20 Galen at $\S 5^{2}$ cites a passage from an otherwise lost play by Euripides (fr. 814 Mette, fr. 964 Nauck) in which the speaker - Theseus - says that he learned from a wise man to imagine constantly disasters that might hit him, so that if one were to occur it would not be novel and affect his soul. He cites it again at $\S 77$. If the reading i $\pi \varepsilon \dot{p}($ p. $23.6 \mathrm{BJP})$ is correct Galen takes Theseus to speak on behalf of Euripides himself, who had reportedly studied with the philosopher Anaxagoras, a tradition recorded by Cicero, Tusc. 3.30. See also Nutton ad loc. (n. 114). For the same quotation see PHP 4.7.10-11 (Posid. F165 EK) where he takes it from the Stoic Posidonius and also refers to Anaxagoras who famously said when he was told about his son's dead: 'I knew I had begotten a mortal.' 
something elevated but lies for grabs for anyone with a bit of sense and some experience of life.

\section{$3 \quad$ Magnanimity}

In Ind. the virtue, or excellence, enabling us to cope with the blows dealt by fate and so avoid becoming distressed is 'greatness of soul' or magnanimity ( $\mu \varepsilon \gamma \alpha \lambda \circ \psi v \chi i \alpha) .{ }^{21}$ Thus at Ind. 50-51, p.16.10-19 BJP Galen says:

Not to be distressed ( $\mu \grave{\eta} \lambda v \pi \eta \theta \hat{\eta} \nu \alpha \mathrm{l})$ at the loss of all my drugs, all my books, and, besides, the recipes of major drugs, as well as the writings on them I had prepared for publication along with many other treatises [...], that is already a prime display of nobility ( $\gamma \varepsilon v v \alpha i o v)$ and nigh on magnanimity ( $\mu \varepsilon \gamma \alpha \lambda \circ \psi v x i \alpha \varsigma)$. What led me to such magnanimity you already know first because you were brought up with me from the start and educated alongside me (translation Nutton's).

Galen goes on to explain that in addition to upbringing and education he had profited from his observations of political life in Rome, which had driven home to him the need to remind oneself of everything one might possibly suffer, i.e.

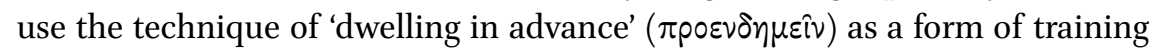
$\left(\S 5^{2-53)}\right.$. Once again we find the same sources of moral success which Galen often links and stresses: upbringing, education, training (see section 2 above). For our present purposes it may be observed that the magnanimity Galen has in mind is the mental or moral strength which results when these factors work to one's advantage so that one is not, or not to the same extent, distressed because of trouble. Further, it may be noted that Galen does not claim to have reached the state of magnanimity but something close to it. A related passage On Affected Parts viII, pp. 301-302 K. links Galen's notion of magnanimity as invulnerability to distress to that of tension:

In those in whom the vital tension is weak and who experience strong psychic affections from lack of education, the substance of the soul is

21 Already Gill, Naturalistic Psychology in Galen and Stoicism, 2010, p. 264 has pointed out that Galen characterizes magnanimity in Stoic terms rather than Aristotelian ones; he was followed by Kotzia, P., 'Galen, De indolentia: Commonplaces, Traditions, and Contexts,' 2014, p. 107. Nutton, Galen, Avoiding Distress, 2013, p. 92 n. 94 refers to the Epicureans alongside the Stoics. 
easily dissoluble. Of people of this kind some have indeed died from distress, albeit not instantly [...]. But no magnanimous man ever met his death either as a result of forms of distress or other affections stronger than distress, for the tension of their soul is strong and its affections small. ${ }^{22}$

It is interesting to note that Galen here seems to ascribe a crucial role to education rather than natural endowment, but he may take this for granted. What this passage adds is the notion of the soul's tension (Tóvos), which is best

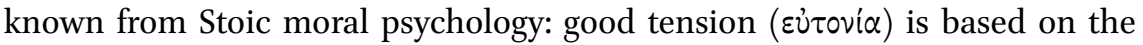
right balance of the psychic pneuma enabling the soul to withstand the impact of incoming impressions, whereas lack of tension ( $\left.\dot{\alpha} \tau o v^{\prime} \alpha\right)$ is linked to mental weakness $\left(\dot{\alpha} x p \alpha \sigma^{\prime} \alpha\right)$ and a soul prone to emotion. ${ }^{23}$ It is especially the second scholarch Cleanthes who seems to have stressed the notion of mental strength in relation to moral excellence. ${ }^{24}$ For him and other Stoics these notions refer to corporeal realities, in particular the tension of the psychic pneuma. Galen does not subscribe to the Stoic theory of a pneumatic soul and is reluctant to pronounce upon the substance (ov $\left.\sigma^{i} \alpha\right)$ of the soul, to which he nonetheless refers in the above passages. But what may have weighed a great deal for him is the fact Plato too speaks of the soul's tension (and relaxation) in Republic III, in a passage dealing with the impact of particular forms of education on the souls of the prospective guardians (411e-412a; cf. 411a), which may in fact have inspired the Stoics to introduce the idea in the corporealist psychology they developed. ${ }^{25}$

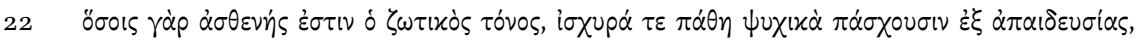

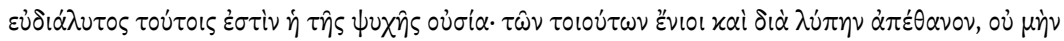

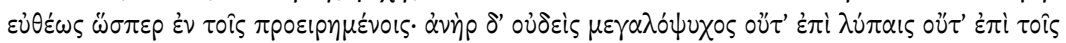

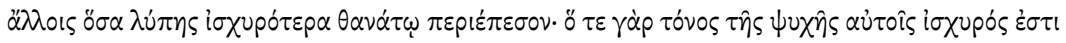

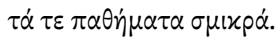

23 On the soul's $\tau$ tóvos and related terms ee esp. the verbatim fragments from Chrysippus' On Affections preserved by Galen, $P H P$ IV.6 and printed by Von Arnim as SVF III, 473.

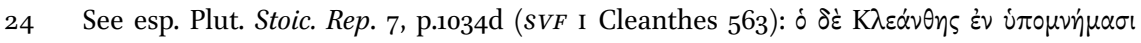

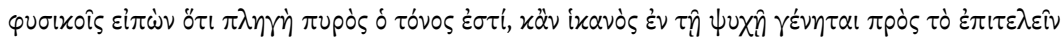

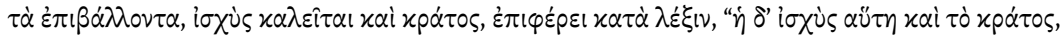

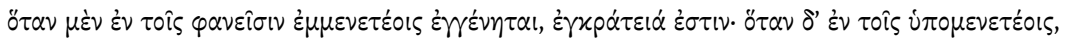

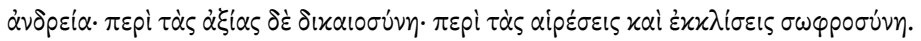

25 On Galen's notion of mental tension and the Platonic and Stoic backdrop see Trompeter, J. 'Die gespannte Seele: Tonos bei Galen.' Phronesis 61.1, 2016, pp. 82-109; cf. also Vegetti M., 'I nervi dell'anima,' in J. Kollesch \& D. Nickel (eds.) Galen und das hellenistische Erbe. Verhandlungen des 4. Internationalen Galen-Symposiums, Stuttgart, Franz Steiner Verlag, 1993, pp. 63-77. 
Galen links magnanimity to another notion as well: contempt, viz. of possession or what he elsewhere in Ind. calls human matters. Here contempt means looking down on them as small or unimportant, that is to say, have the correct view on their true value. This fortifies the soul so that it can deal with their loss. The idea is also in the background of Galen's exchange with the troubled young man as recounted in An. dig. (see above, p. 202): the young man is kept from his sleep by small things, whereas Galen is not even troubled by big ones. In Ind. Galen's own father provides an example of this attitude. ${ }^{26}$ This can also be expressed as the ability of rising above them so that they look small. But again Galen makes it clear that he himself cannot rise above all forms of adversity. Thus he would not make light of the prospect of being roasted in the bull of Phalaris (as the Epicurean and Stoic varieties of the sage were supposed to do). ${ }^{27}$

The notion of magnanimity at issue here is Stoic rather than Aristotelian, even if present-day students may be more familiar with Aristotle's magnanimous person as portrayed in Nicomachean Ethics IV.3: the not entirely likeable character who is conscious of his own worth and acts accordingly. The Stoic notion, however, is not so much concerned with pride and self-esteem but closely related to courage. Galen in one passage from $P H P$ seems turn the Stoic notion against the Stoic Chrysippus and so must have been fully conscious of its provenance. ${ }^{28}$ Magnanimity $(\mu \varepsilon \gamma \alpha \lambda \circ \psi v \chi i \alpha$,$) is classed as a subspecies of courage$ ( $\alpha \delta \delta \rho \varepsilon i \alpha)$ in early Stoic texts, viz. "the knowledge that makes us rise above those things that are of such a nature that they happen to wise and non-wise alike." ${ }^{29}$ This clearly refers to the fated, unavoidable events of the potentially frightening and distressing kind, depending on whether one is capable of assessing

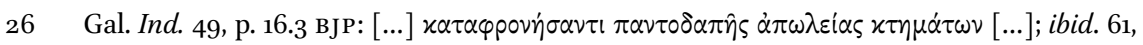

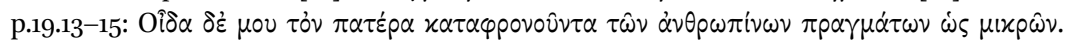

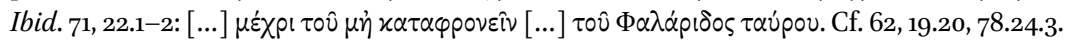

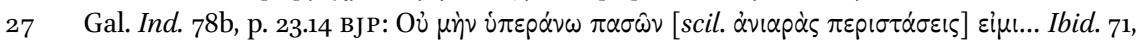

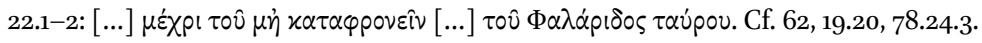

$28 \quad P H P$ 3.2.18 De Lacy (cf. $S V F$ II, 906, p. 254, 1-18): Galen sarcastically speaks of the magnanimity of the Stoic Chrysippus as proven from his undeterred attitude in citing poetic lines that actually tell against the Stoic cardiocentric doctrine of the soul he has set out to defend. Galen here uses a Stoic virtue to bestow mock-praise on a Stoic.

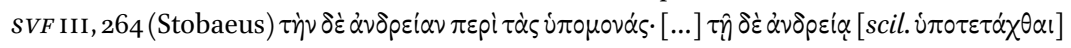

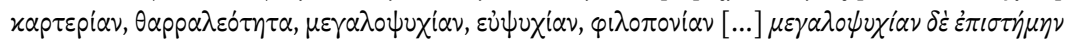

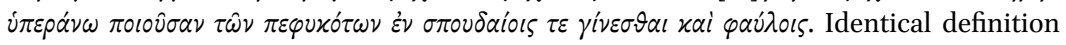
at $S V F$ II, 269 (ps. Andronicus). Cf. $s V F$ III, 265 (Diog. Laert. 7.92): $\tau \dot{\eta} \nu \delta \dot{\varepsilon} \mu \varepsilon \gamma \alpha \lambda \circ \psi v \chi i \alpha \nu$

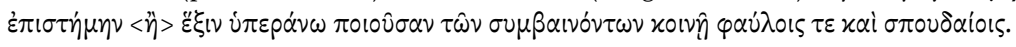


their value correctly (i.e. as indifferents). ${ }^{30}$ This, then, is the notion with which we find Galen operating in Ind. The prominence it is given here may reflect the fact that well before Galen's time magnanimity was upgraded vis-à-vis courage, a move that may perhaps be associated with the name Panaetius of Rhodes (ca. 185-109 BCE) and, at least as its status is concerned, reflect Aristotelian influence. ${ }^{31}$ Thus Cicero in his On Duties, presumably drawing on Panaetius' work of the same title, presents magnanimity among the four main or generic excellences as that which resides in the "greatness and strength of an elevated and invincible mind" marked by a "contempt for human matters." 32 Had the early Stoics already typified magnanimity as the ability of rise above human life's ups and downs as inconsequential, the idea is now also expressed in terms of holding them in contempt or despising them, as in Galen's text. Panaetius' associate Hecato of Rhodes (who may have lived on well into the first century ВСЕ) made the further step of classing courage, alongside mental health, strength and beauty, among a new class of excellences or virtues, viz. the nontheoretical ones, which unlike the theoretical ones do not involve assent and, according to the report given by Diogenes Laertius, could even be possessed by the non-wise. ${ }^{33}$ Like the innate aptitude for moral progress towards excellence, good mental qualities of this sort had been acknowledged by the early Stoics, who classed them as preferred indifferents. ${ }^{34}$ Hecato's move may have been motivated by his wish to integrate the qualities in question more completely into the Stoic ethical system. ${ }^{35}$ For our purposes suffice it to note that Hecato retained the link between theoretical and non-theoretical excellences, describing them as supervening on the theoretical ones: thus health is said to be co-extensive with and attendant upon temperance. ${ }^{36}$ This then must also have been the relation between magnanimity, a theoretical virtue, and courage. But

30 As is clear from the definition of courage, the generic concept: $s V F$ II, 262 (Stob.): $\dot{\alpha} v \delta \rho \varepsilon i \alpha v$

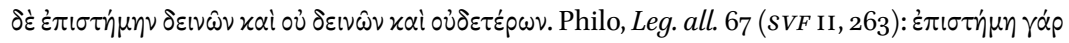

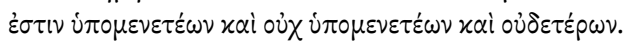

31 See Dyck, A., 'Panaetius' conception of $\mu \varepsilon \gamma \alpha \lambda \circ \psi v \chi i \alpha$,' Museum Helveticum 38, 1981, 153-161.

32 Cic. Off. I, 5, 15 (= T 56 Alesse, fr. 103 vStr., part): omne quod est honestum, id quattuor partium oritur ex aliqua. Aut enim in perspicientia veri sollertiaque versitur, aut in hominum societate tuenda tribuendoque suum cuique et rerum contractarum fide, aut in animi excelsi atque invicti magnitudine et robore, aut in omnium quae fiunt und dicuntur ordine et modo, in quo inest modestia et temperantia. Cf. ibid. I, 13 (= T 55 Alesse, fr. 98 v.Str., part) magnitudo animi exsistit humanarumque rerum contemptio; cf. III, 96 and Posidonius ap . Sen. Ep. 87.32, 35 (magnitudo animi) = F 170 EK.

33 D.L. 7.90 = Hecato Fr. 6 Gomoll.

34 See $S V F$ III, 127, 136.

35 For more discussion and further references see Pohlenz (1984) 240-241, (1980) 123-124.

36 D.L. $7.90=$ Hecato Fr. 6. 
if theoretical virtue entails non-theoretical virtue, non-theoretical virtue does not entail theoretical virtue, since non-wise persons can have non-theoretical virtues such as courage. But how exactly the non-theoretical qualities functioned, must remain a moot point. Maybe they constituted a person's natural aptitude for moral progress and the attainment of virtue in the theoretical sense but this must remain an assumption for lack of evidence. But we do possess an argument from Hecato's second book On Goods on magnanimity as the basis for the Stoic thesis that virtue is sufficient in itself for happiness:

For if, he says [scil. Hecato], magnanimity is sufficient for raising us above everything and magnanimity is a part of virtue, then too virtue will be sufficient in itself for happiness, despising all things that seem troublesome (transl. Hicks, slightly modified). ${ }^{37}$

This fragment is not only concerned with the same notion of magnanimity as is used by Galen, ${ }^{38}$ but it makes magnanimity the key to the excellent person's invulnerability. Hecato no doubt reflects the prominence of the notion among Stoics from Panaetius onwards. This prominence itself is also reflected by Galen in his turn.

The idea of taking a bird's eye view at human affairs as a way of achieving tranquillity is of course widespread, especially in Stoic and Cynicizing literature, and not necessarily in conjunction with the specific virtue of magnanimity. There is something of this attitude in Galen too, although it neither leads to the degree of detachment from the comédie humaine one encounters in some Cynic and even Stoic texts, where laughing can be presented as the only adequate response of the philosopher. ${ }^{39}$

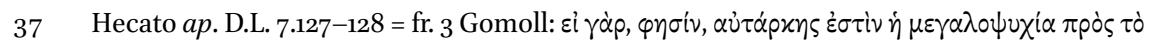

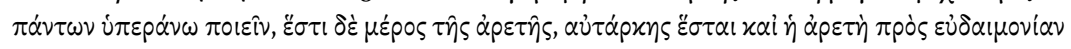

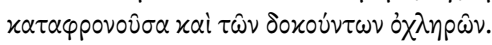

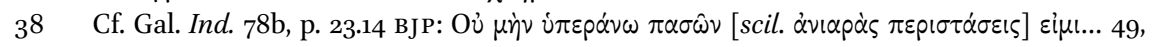

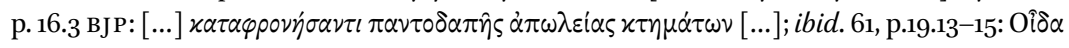

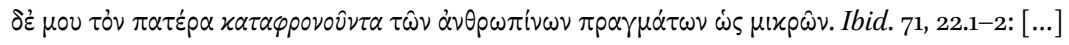

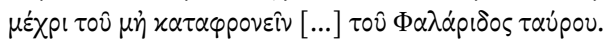

39 Even the Stoic Seneca can speak like this: Ep. 41.5: vis isto divina descendit; animum excellentem, moderatum, omnia tamquam minora transeuntem, quidquid timemus optamusque ridentem ... Cf. ibid. 78.18 (laughing while under torture), 80.6 (laughing in spite of poverty). For a bird's eye passage in his work see also the beginning of the second book of the Natural Questions. 
Despising human affairs as of little value - a moral attitude Galen attributes to his father and says he has adopted himself in his old age (Ind. § 61; cf. 65) saves one from distress: one no longer supposes that one has been deprived of something big ( $(66)$. This of course raises the question of where true value lies. What is the real good? In what follows at $\S$ 62-68 Galen considers the positions of two philosophical schools: Epicureanism and Stoicism. Having said that his father rejected common, non-philosophical hedonism, Galen adds that he never praised those who were satisfied with being free from pain or distress in their souls - a clear reference to the Epicureans ( $\$ 62)$ : Galen's father felt that the good must be of its nature something bigger than just being free from something (ibid.). Here it is to be understood that Galen follows his father. At the end of the section (§68), speaking now on his own behalf, he adds an argument against the Epicurean ideal of remaining undisturbed: this goes against the observable fact human beings and indeed all animals want to be active in both mind and body, as he had established earlier in his work (now lost) Against (or On) Epicurus.

In $\S \S 63$ and 64 he considers the position of those who take the good to be "knowledge of matters both human and divine:"

(63) If someone will [...] hold that the good is a knowledge of matters both human and divine, then I see that mankind possesses only a very small part of this, and that, if it is so very small, we cannot have a precise knowledge of everything else also. (64) But someone who has not even a general knowledge of matters human and divine can neither make even in part or scientifically a decision on what to choose and what to avoid (translation Nutton's). ${ }^{40}$

Commentators have been quick to identify the definition of the good as Aristotelian..$^{41}$ However, they have been unable to produce sound textual support fort his identification. In fact we have to look elsewhere, to Stoicism. Thus

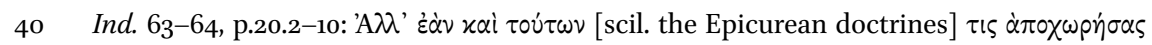

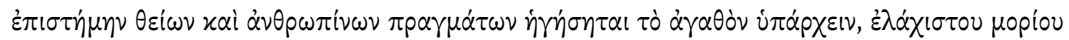

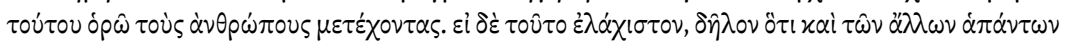

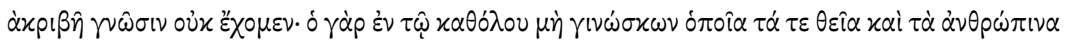

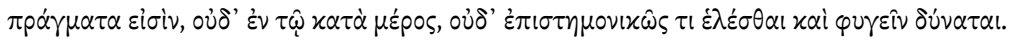

41 Thus Boudon-Jouanna ad loc. ("La terminologie est clairement Aristotélicienne"), Nutton ad loc. (n. 104), citing Arist. Met. vi.1, 1026a18-32; XI.7, 10641-4, following Hankinson, R.J., Galen, On the Therapeutic Method, Books I and II, 1991, p. 82, who cites them in connection 
we encounter the same definition with explicit attribution tot he Stoics in the proem to the Aëtian Placita: "The Stoics have said that wisdom is the knowledge of things human and divine, whereas philosophy is the exercise of expertise in utility."42 And Sextus Empiricus borrows the same definition from his dogmatist opponents, who, here as elsewhere, are to be identified as the Stoics: "Philosophy is the pursuit of wisdom, and wisdom is the knowledge of things divine and human."43

As we have seen, Galen objects to this conception of the good that it lies beyond the reach of mankind. Our knowledge is limited and imprecise - which means that we cannot makes decisions about what to choose and what to avoid on the basis of knowledge ( $\dot{\varepsilon} \pi \sigma \tau \eta \mu o v i x \omega \hat{\omega})$ ). Leaving aside for a moment the question whether this is a fair piece of criticism of Stoicism and a strong argument, it is worth noting that in addition to the definition of the good we have here another echo of a Stoic definition, viz. that of moderation as the knowledge of what to choose and what to avoid, as can be attested by several sources. $^{44}$

Having established that Galen is engaging with the Stoics, we may now take a closer look at his argument. As we have seen, he presents Stoicism as requiring general knowledge of an impossibly broad range of subjects. This is unattainable so we are left empty-handed in regard to the decisions we have to make in particular situations also. In fact, our knowledge is very limited.

with the same definition of philosophy as distinguished from the liberal arts used by Galen at $M M$ I.2, X p. $2 \mathrm{~K}$.

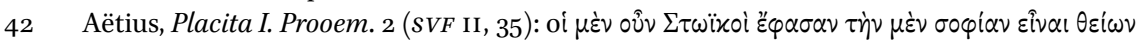

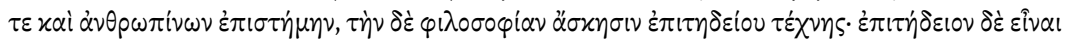

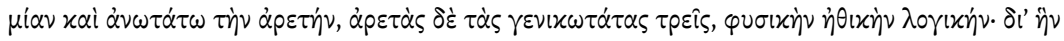

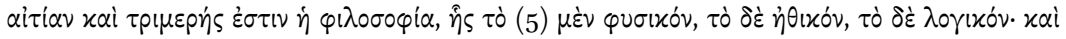

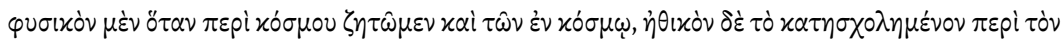

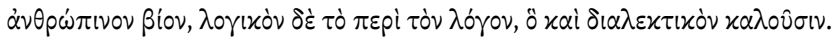

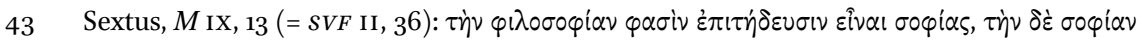

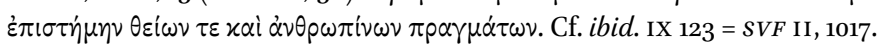

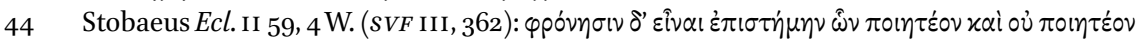

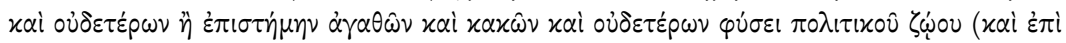

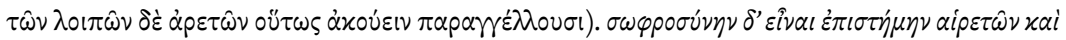

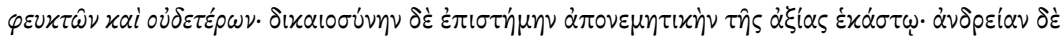

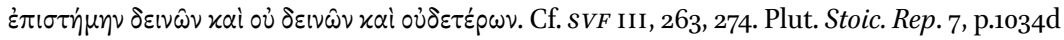

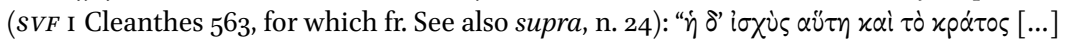

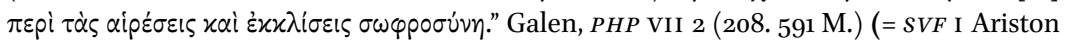

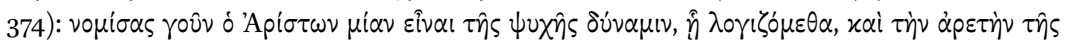

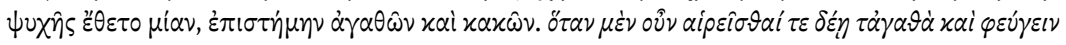

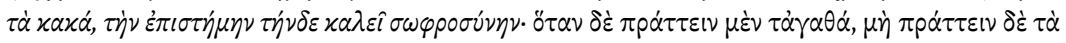

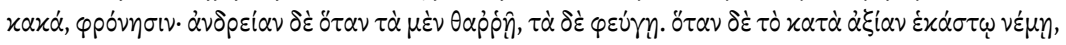

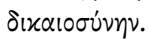


Galen goes on to explain that this realization kept him from politics and public office, all the more so since he saw that even decent politicians could do little for people in need $(\S 64)$. This point may reflect the Stoic injunction to take part in politics and government: so Stoicism does not equip us with workable principles for taking care of other people's lives through politics as well as leading our own lives. He goes on $(\S 65)$ to say that "brought up in this way of thinking" he always considers "all these things" (i.e. presumably the pursuit of social and political goals) as of little worth. So how could he suppose "leisure, instruments, drugs, books, reputation and riches to be precious"? Here we have some of the items he had indeed lost in the great fire, adding a few others of what the Stoics classed as indifferents such as reputation and riches. Clearly, Galen is now back again at his task of explaining why the losses of the kind he suffered did not distress him (and nor will others in the same category might these occur in the future). But the logic of this passage is not very clear. Nutton indicates some textual uncertainties which may lie behind our difficulties. Galen's critique of Stoicism as failing to provide an attainable ideal and so a workable basis for morality and politics switches to his own limitations and difficulties when he explains why he did not enter politics. This leads to the biggest leap, viz. that Galen looks down on human affairs as of little worth. Ironically, this conclusion states what every decent Stoic would also subscribe to, namely that we should not make our well-being depend on external items such as possessions or a good reputation, for if we do we shall be distressed when we loose them.

After this Galen goes on to wind up his argument, saying that he believes that he has given a full answer to his friends question about avoiding distress $(\S 69)$. However, he does not stop at this point, but presents a conclusion, first about himself ( $\S 69-79)$ and then ( $\S 79$, end-84) mankind in general. At $\S 71$ he summarizes his own relation to distress as follows:

Now I cannot say if there is anyone so wise that he is entirely free from affections, but I have a precise knowledge of the degree to which I am such a one: I do not care about the loss of possessions without quite being deprived of them all and sent to a desert island, or of bodily pain without quite making light of being placed in the bull of Phalaris. What will distress me is the ruination of my homeland, or a friend being punished by a tyrant, and other similar things, and I pray to the gods that none of this should ever happen to me (translation Nutton's).

First we have a reference to Stoic apatheia: Galen doubts whether anyone is so wise as to have attained this ideal and be entirely free of them. But speaking 
for himself he makes it clear that he does not care about loss of possessions or bodily pain. The claim here is that in these cases he is free from affections, most notably distress. But there are exceptions. He goes on to give examples of extreme misfortune that will distress him: a homeland ruined, a friend punished (some of his examples surfaced earlier in connection with Commodus' tyrannical rule). From the Stoic point of view these things count as indifferent and hence, ideally, should not be allowed to trigger an emotional response either. ${ }^{45}$ Galen does not say that a moderate emotional response is in order here. Neither here, nor elsewhere in his treatise, does he say or imply that the personal catastrophe he suffered in loosing his books, drugs and recipes, elicited distress only to a moderate degree. This is not his personal ideal. The final part shows that the emphasis is different. Galen says he will fortify his soul through training: without ever being able to respond like the Stoic wise man he can

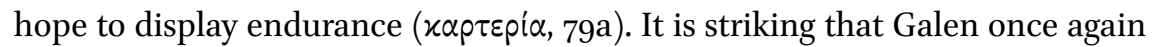
dwells on the method of anticipating misfortune as the only training he finds helpful against painful bad turns $\left(\S 76^{-}-77\right)$.

As we have seen, Galen next turns to mankind in general, attributing people's unhappiness to their being immoderately ( $\dot{\alpha} \mu \varepsilon \dot{\varepsilon} \tau \omega \varsigma)$ attached to esteem, wealth, reputation and political power. Their insatiable desires will not fail to make them unhappy (81). There is also a reference to those who are only moderately ( $\mu \varepsilon \tau$ pi $\left.^{\prime} \omega \varsigma\right)$ attached to these things, but the text is uncertain at this point: Galen probably implies that the moderate ones are best placed to avoid unhappiness, at least to some degree. In this connection Galen praises his friend for his simple lifestyle and curbing his desires.

Galen does not apply what he says here to himself, but comments on the situation in which other people find themselves. For them moderation of desire and emotional attachment is the best they can achieve. Does this place Galen in the metriopatheia camp? ${ }^{46}$ I think not. The objects in question include some of those which Galen had said he does not mind loosing at all, most notably

45 As Graver points out in 'The Weeping Wise: Stoic and Epicurean Consolations in Seneca's 99th Epistle,' in T. Fögen, ed. Tears in the Graeco-Roman World, Berlin-New York, De Gruyter, 2009, pp. 235-252 (p. 237), Stoic authors of works of consolation such as Seneca regularly give some leeway to grief experienced in moderation (though not to grieve at all would be better): see e.g. Ep. 63.1 .

46 Cf. Hankinson, R. J., 'Actions and passions: affection, emotion and moral self-management in Galen's philosophical psychology,' in J. Brunschwig \& M. Nussbaum (eds.) Passions \& Perceptions. Studies in Hellenistic Philosophy of Mind, 1993, pp. 203-204, who, writing on this issue long before the discovery of Ind., notes that no clear answer tot his question is to be found in the texts but proceeds to offer a tentative suggestion, viz. that Galen may have advocated extirpation only in the case of excessive and uncontrollable emotion, which is pathos in the sense of disease, i.e. an unnatural condition, while accepting emotion in the 
possessions and political power. When he adds that he expects to be distressed by being deprived of life's barest necessities, he is just marking off his own position against the moral heroics of diehard Stoics such as Musonius Rufus (cf. $§ 73$, where he dismisses Musonius Rufus, who had prayed to Zeus to send him any eventuality). But on the other hand we have seen that Galen stresses his complete indifference to certain bad turns or losses, which is definitely not an expression of metriopatheia but rather of selective apatheia, at least as an ideal for himself to pursue; others may get no further than respond with moderate emotion to misfortunes. One may compare Philo, Leg. Alleg. III, 129-132, who draws a distinction between metriopatheia as appropriate to the man of median virtue who is still progressing (symbolized by Aaron) and apatheia as proper to the accomplished sage (symbolized by Moses), as if, in John Dillon's apt words, the concepts could be accommodated on a sliding scale. ${ }^{47}$

Platonists could not derive from Plato's work clear and unequivocal guidance when it came to deciding on which side they should be in this controversy, which had arisen some time after Plato under the influence of Stoicism. Like Philo, Platonists of the Imperial period display a striking unwillingness or inability to keep the two competing alternatives apart. ${ }^{48}$ Galen, not an adherent of the Platonist (or any other) school but a great admirer of Plato, also combines the two options. An emphasis peculiar to him seems to be his doubts as to whether complete apatheia (which may be desirable as such) is attainable in real life, given our basic needs and vulnerability as human beings.

\section{5}

\section{Conclusion}

I have been highlighting a few concepts that seem central to the position developed by Galen in regard to distress. Even if he stresses the role of natural aptitude, family background and upbringing, he is not averse to philosophy but on the contrary draws on philosophical concepts, arguments and debates

sense of the natural activity of the soul's affective part. But instead of being a compromise position this would just boil down to metriopatheia.

47 Dillon, J., "Metriopatheia and Apatheia": Some Reflections on a Controversy in later Greek ethics,' 1983, p. 515. For metriopatheia and apatheia as corresponding to two different stages of moral progress see Plotinus, Enn. 1.2.2 (14-18) and 1.2.3 (20), who links them to ordinary 'civic' virtue and what 'purified' virtue respectively. Cf. Sorabji, R. Emotion and Peace of Mind, 2000, p. 203. Contrast Seneca, Ep. 116 for a clear statement of the difference between moderation and eradication from a Stoic point of view.

48 Dillon, J., "Metriopatheia and Apatheia": Some Reflections on a Controversy in later Greek ethics,' 1983 , pp. 515-516. 
to a greater degree than sometimes has been assumed, especially in the case of Stoicism. There is the prominence given to the Stoic virtue of magnanimity. But we have found more Stoic elements. Indeed, the distinction between natural aptitude, training and philosophical education is philosophical in itself, reflecting as it does Stoic distinctions and debates. Another recurrent element is the ideal of wisdom. Here Galen demarcates his position vis-a-vis Stoicism or at least its hardline variety that peddles a form of moral heroics and an unattainable ideal of complete freedom from emotion (apatheia). As we have seen, the alternative developed by Galen is not aimed at moderation of emotion. Affections are to be avoided as much as possible and with regard to some objects or situation it is possible to avoid them completely, as in the case of Galen's response to the loss of his books, drugs and recipes. For many other people moderation of emotion is the most they can achieve.

\section{References}

Asmis, E. 'Galen's De indolentia and the Creation of a Personal Philosophy', in Rothschild \& Thompson eds., Galen's De indolentia. Essays on a newly Discovered Letter. Studien und Texte zu Antike und Christentum 88. Tübingen: Mohr Siebeck, 2014, pp. 127-142.

Boudon - Millot, V. \& J. Jouanna, eds., Galien, Tome IV: Ne pas se chagriner. Avec la collaboration de A. Pietrobelli. Paris, Les Belles Lettres, 2010.

Deichgräber, K., 'Galen als Erforscher des menschlichen Pulses. Ein Beitrag zur Selbstdarstellung des Wissenschaftlers (De dignotione pulsuum I 1),' Sitzungsberichte Ak. Wiss. Berlin. Kl. Sprache, Literatur und Kunst, 1956, 3 (Berlin: Akademie-Verlag 1957).

Dillon, J., "Metriopatheia and Apatheia": Some Reflections on a Controversy in later Greek ethics', in J. P. Anton \& A. Preuss (eds.) Essays on Ancient Greek Philosophy, vol. II (Albany: SUNY Press) 1983, 508-517; repr. as Study nr. viII in J. M. Dillon, The Golden Chain. Studies in the Development of Platonism and Christianity, Aldershot, Variorum 1990.

Dyck, A., 'Panaetius' conception of $\mu \varepsilon \gamma \alpha \lambda \circ \psi v \chi \chi_{1} \alpha$,' Museum Helveticum 38, 1981, 153-161. Garofalo, I. \& A. Lami, eds., Galeno. L'anima e il dolore. De indolentia. De propriis placitis. Classici greci e latini. Milano, Bur Rizzoli, 2012

Gill, C. 'Peace of Mind and Being Yourself: Panetius to Plutarch,' ANRW II.36.7, 1994, 4599-4640.

Gill, C., Naturalistic Psychology in Galen and Stoicism, Oxford, 2010, [262-266].

Graver, M., 'The Weeping Wise: Stoic and Epicurean Consolations in Seneca's 99th Epistle,' in T. Fögen, ed. Tears in the Graeco-Roman World, Berlin-New York, De Gruyter, 2009, pp. 235-252. 
Hankinson, R. J., Galen, On the Therapeutic Method, Books I and II. Translated with an Introduction and Commentary, Clarendon Press, Oxford, 1991.

Hankinson, R. J., 'Actions and passions: affection, emotion and moral self-management in Galen's philosophical psychology,' in J. Brunschwig \& M. Nussbaum (eds.) Passions \& Perceptions. Studies in Hellenistic Philosophy of Mind. Proceedings of the Fifth Symposium Hellenisticum, Cambridge, CUP, 1993, pp. 184-222.

Kaufman, D. H., 'Galen on the Therapy of Distress and the Limits of Emotional Therapy,' Oxford Studies in Ancient Philosophy 47, 2014, pp. 275-296.

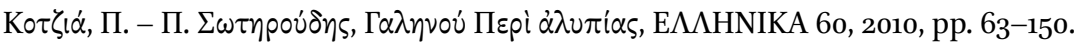

Kotzia, P., 'Galen $\pi \varepsilon p i ~ \alpha \lambda v \pi i \alpha \varsigma:$ title, genre and two cruces,' in Manetti, D. ed., Studi sul De Indolentia di Galeno, 2012, pp. 69-92.

Kotzia, P., 'Galen, De indolentia: Commonplaces, Traditions, and Contexts,' in Rothschild \& Thompson, Galen's De indolentia. Essays on a newly Discovered Letter, 2014, pp. 91-126.

Manetti, D. ed., Studi sul De Indolentia di Galeno. Vol. 4 of Biblioteca di "Galenos"; Contributi alla ricerca sui testi medici antichi. Pisa: Fabrizio Serra, 2012.

Nutton, V., Galen, Avoiding Distress (translation and introduction) in P. N. Singer et al. (eds.) Galen. Psychological Writings, Cambridge, CUP, 2013, pp. 43-106.

Pohlenz, M., Die Stoa. Geschichte einer geistigen Bewegung, 2. Band, Göttingen, Vandenhoeck und Ruprecht, 5. Auflage, 1980.

Pohlenz, M. Die Stoa. Geschichte einer geistigen Bewegung, 1. Band, Göttingen, Vandenhoeck und Ruprecht, 6. Auflage, 1984.

Rothschild, C. K. and T. W. Thompson, eds., Galen's De indolentia. Essays on a newly Discovered Letter. Studien und Texte zu Antike und Christentum 88, Tübingen, Mohr Siebeck, 2014.

Sorabji, R., Emotion and Peace of Mind. From Stoic Agitation to Christian Temptation, Oxford, OUP, 2000.

Stirewalt, L. M., 'The Form and Function of the Greek Letter-Essay,' in K. P. Dornfried, The Romans Debate. Revised and Expanded Edition, Peabody Mass., Hendrickson Publishers, 1991, pp. 147-171.

Stirewalt, L. M., Studies in Ancient Greek Epistolography, SBL Resources for Biblical Study 27. Atlanta, GA, Scholars Press, 1993.

Trompeter, J., 'Die gespannte Seele: Tonos bei Galen.' Phronesis 61.1, 2016, pp. 82-109.

Vegetti M., 'I nervi dell'anima,' in J. Kollesch \& D. Nickel (eds.) Galen und das hellenistische Erbe. Verhandlungen des 4. Internationalen Galen-Symposiums, Stuttgart, Franz Steiner Verlag, 1993, pp. 63-77; repr. In M. Vegetti, Dialoghi con gli antichi. A cura de Silvia Gastaldi et al. (Akademia Verlag 2007) pp. 279-296.

Vegetti, M., Galeno. Nuovi scritti autobiografici. Introduzione, traduzione e commento di - . Carocci editore, 2013.

Weisser, S., Eradication on modération des passions. Histoire de la controverse chez Cicéron et Philon d'Alexandre, Monothéismes et Philosophié, forthcoming from Brepols (Turnhout) (non vidi). 